\title{
EVALUATION OF RESPONSE TO ANTI-LEPTOSPIRA BACTERIN VACCINATION IN PREGNANT EWES AND THE PASSIVE TRANSFER OF ANTIBODIES TO THEIR OFFSPRING
}

\author{
AVALIAÇÃO DA RESPOSTA À VACINAÇÃO COM BACTERINA ANTI-LEPTOSPIRA \\ EM OVELHAS GESTANTES E DA TRANSFERENCIA PASSIVA DOS ANTICORPOS \\ A SUAS CRIAS
}

\author{
Ligia Pinho CUCCATO ${ }^{*}$; Anna Monteiro Correia LIMA ${ }^{1}$; Thais Fernanda Martins dos \\ REIS ${ }^{1}$; Caroline Lopes QUEIROZ ${ }^{1}$; Ana Beatriz Gacez BUIATTE ${ }^{1}$; Andreia Zago CIUFFA ${ }^{1}$; \\ Dayane Olímpia GOMES ${ }^{1}$; Vinícius Buiattte de Andrade ALVES ${ }^{1}$; \\ Fernanda ROSALINSKI-MORAES ${ }^{1}$
}

1. Laboratório de Doenças Infectocontagiosas, Universidade Federal de Uberlândia, Faculdade de Medicina Veterinária, Uberlândia, MG, Brasil.ladocvetufu@yahoo.com.br; fernanda.rosalinski@ufu.br

\begin{abstract}
Leptospirosis in sheep is often underestimated, and leads to great economic losses for the sheep farming industry. The aim of this study was to evaluate the humoral immune response in pregnant ewes, after the injection of a commercial polyvalent vaccine for leptospirosis, and to observe the transmission of anti-Leptospira antibodies through the colostrum to the offspring. For this, 24 pregnant ewes were vaccinated for leptospirosis. Blood samples were collected prior to vaccination and then $7,14,21,28,35,42$ and 49 days after vaccination. In order to evaluate passive immunity transfer, blood samples of 32 lambs were collected during the first 48 hours after birth, and another collection was performed 10 to 21 days after birth. The lambs were placed into 2 groups: Group A $(n=16)$ : singleton lambs; and group $B(n=16)$ : twins. The sera samples were submitted to the Microscopic Agglutination Test (MAT), in which 21 Leptospira serovars were tested. The results were analyzed in a descriptive form. The number of sheep reactive to MAT gradually increased until 21 days after vaccination, and decreased right after. Of all the serovars contained in the vaccine, the largest proportion of animals were seroconverted to Hardjoprajtino serovar, Serjoe serogroup. AntiLeptospira antibodies transferred through colostrum to lambs were detected by MAT in the serum collected 2448 hours after birth. It was observed that $65.6 \%$ ( 21 out of 32 ) of the lambs were reactive. In the subsequent collections that occurred from 10 to 21 days after birth, a decrease in the number of animals reactive to the MAT was detected. There was no significant statistical difference for the passive transfer of antibodies between single or twin lambs.
\end{abstract}

KEYWORDS: Immunization. Leptospirosis. Sheep.

\section{INTRODUCTION}

Leptospirosis is a disease caused by bacteria that entails important sanitary consequences due to its zoonotic aspect (HIGINO; AZEVEDO, 2014; SHIOKAWA et al., 2018). Currently, the genus Leptospira comprises 22 species divided in three groups. On Group I there are pathogenic species that cause severe disease as Leptospira interrogans, Leptospira kirschneri, Leptospira noguchii, Leptospira borgpetersenii, Leptospira alexanderi, Leptospira weilii, Leptospira santarosai, Leptospira kmetyi, Leptospira alstoni and Leptospira mayottensis. Group II includes Leptospira of intermediate pathogenic importance: Leptospira licerasiae, Leptospira wolffii, Leptospira fainei, Leptospira broomii and Leptospira inadai. Leptospira idonii, Leptospira meyeri, Leptospira terpstrae, Leptospira biflexa, Leptospira vanthielii, Leptospira yanagawae and Leptospira wolbachiisaprophytes, non-pathogenic leptospirae that do not cause diseases in humans or animals, belong to Group III (PUCHE et al., 2018). As there is no host specificity, any species of Leptospira can infect wild and domestic animals, and humans (ELLIS, 1994; CICERONI et al., 2000; HERMANN et al., 2011).

In sheep, leptospirosis can manifest itself in acute, subacute or chronic form (ADLER, 2015). The acute form usually happens as outbreaks, and is characterized by hematuria, hemoglobinuria, jaundice, abortion, and death of lambs in the first weeks of life (MARTINS et al. 2011).

Ciceroni et al. (2000) stated that sheep and goat are less susceptible to leptospirosis, and that most infections have subclinical evolution. But 
these animals can develop chronic kidney infection, and eliminate bacteria through urine for long periods, spreading it to other animals and humans (LILENBAUM et al., 2009).

Generally, leptospirosis is related to reproductive disorders, such as abortion, return to estrus and stillborn lambs. It also decreases productivity, which results in great economic losses (LILENBAUM et al., 2009; HIGINO; AZEVEDO, 2014; SILVA et al., 2019).

A way to prevent leptospirosis is through herd immunization with vaccines formulated with bacterins, prepared with the most prevalent serologic variants, for particular animal species from a specific region (HERRMANN et al., 2011). The vaccine is an important resource to promote immunity in the herd, decrease clinical signs of the disease, and reduce morbidity rates (MOREIRA, 1994; HERMANN et al., 2011).

Pregnant females and young animals are part of the risk groups for leptospirosis (CICERONI et al., 2000). The vaccination of pregnant ewes in the last months prior to labor may avoid the infection in them and their offspring. That is because there is immunoglobulin transfer from ewes to lambs during gestation through placenta, or right after birth through the ingestion of colostrum (TIZARD, 2014).

Because ruminants have syndesmochorial placenta, which doesn't allow the passage of immunoglobulins from mother to fetus during gestation, these animals need to acquire them right after birth through colostrum ingestion. The immunoglobulin absorption from colostrum ensures immune activity in the first moments of life, when the lambs don't have a full response capacity
(TIZARD， 2014; HERNADEZ-CASTELLANO 2015).

Since leptospirosis has an important role in economy and public health, and there is lack of information in the literature regarding immunoprophylaxis in sheep, the goal of this study was to evaluate the dynamics of humoral response, induced by the administration of a commercial polyvalent vaccine for leptospirosis in pregnant ewes, as well as to verify the passive immunity transfer to newborn lambs.

\section{MATERIAL AND METHODS}

The research was held at Sheep and Goat Production Center, in the Capim Branco experimental farm, which is part of the Federal University of Uberlândia (UFU) School of Veterinary Medicine. The project was previously approved by the Ethics Committee for Animal Utilization in Federal University of Uberlândia, registered under protocol number 077/16.

The property sheep and goats are bred for lamb slaughtering. Production is conducted on a semi-extensive system, with concentrate supplementation according to the energy requirements for each age group.

In this study, 24 pregnant crossbred Santa Inês-Dorper ewes were used. Sheep were aged from one to six years old. Also, 32 lambs that were born after natural breeding with estrus synchronization were used during this study.

Ewes were immunized with $2 \mathrm{~mL}$ of a commercial polyvalent vaccine made with inactive bacterin (Table 1). Vaccination occurred in the last trimester of gestation, forty days prior to parturition.

Table 1. Composition of the commercial polyvalent Leptospira bacterin that was used for sheep immunization

\begin{tabular}{lll}
\hline Species & Serogroup & Serovar \\
\hline Leptospira borgpetersenii & Tarassovi & Tarassovi \\
Leptospira interrogans & Canicola & Canicola \\
Leptospira interrogans & Icterohaemorrhagiae & Copenhageni \\
Leptospira interrogans & Icterohaemorrhagiae & Icterohaemorrhagiae \\
Leptospira interrogans & Pomona & Pomona \\
Leptospira interrogans & Pyrogenes & Pyrogenes \\
Leptospira interrogans & Sejroe & Wolffi \\
Leptospira interrogans & Sejroe & Hardjo \\
Leptospira kirschneri & Grippotyphosa & Grippotyphosa \\
Leptospira santarosai & Bataviae & Bataviae \\
\hline
\end{tabular}

A single shot of the vaccine was used, since the property already had the habit of immunizing the animals for leptospirosis every six months, starting at the age of three months, with a booster thirty days after the first shot.
Close to parturition, the ewes were grouped according to the date of breeding, in straw bed pens. Parturitions occurred naturally, and there was not any dystocia or disturbance. 
Evaluation of response...

The newborn lambs stayed with their mothers, and the colostrum ingestion occurred naturally and spontaneously during 21 days after birth, which was the period in which this study was held. All lambs received identification tags right after birth, and had their navels cleaned with 5\% iodine solution, twice a day, until fully healed.

Thirty-two lambs were born during this study, being 16 males and 16 females. Sixteen out of 32 lambs were born to singleton-bearing ewes, while 16 were born to multiple-bearing ewes. Thus, lambs were placed into two groups: Group A (singleton lambs) and Group B (twins).

Prior to vaccination, blood was collected from all pregnant ewes (Day zero - D0). The blood sampling was performed by venipuncture of the external jugular vein, using $5 \mathrm{~mL}$ vacuum tubes without anticoagulants, and $25 \times 8 \mathrm{~mm}$ needles. Also,
CUCCATO, L. P.et al.

blood sampling was conducted at days 7, 14, 21, 28, 35, 42 and 49 after vaccinations.

The lambs' blood collection was performed between 24 and 48 hours after birth, and then, after 10 and 21 days. $3 \mathrm{~mL}$ of blood were collected by venipuncture of the jugular vein with syringes and $25 \times 7 \mathrm{~mm}$ needles.

Samples were then sent to the Infectious Diseases Laboratory, Federal University of Uberlândia, School of Veterinary Medicine. The tubes were centrifuged at 3,000 rpm (revolutions per minute) for serum separation. Then, they were stored at $-20^{\circ} \mathrm{C}$ in properly labeled microtubes.

Antibody screening was performed using Microscopic Agglutination Test (MAT) (BRASIL, 1995) under a dark-field microscope. A collection of 21 serovars of Leptospira was used (Table 2).

Table 2. Species, Serogroup and Serovars of Leptospira spp. strains used as antigen in the Microscopic Agglutination Test (MAT) for antibody detection in order to describe soroconvertion of the vaccinated sheep

\begin{tabular}{ccc}
\hline Species & Serogroup & Serovar \\
\hline Leptospira biflexa & Semarang & Patoc \\
Leptospira biflexa & Andamana & Andamana \\
Leptospira borgpetersenii & Javanica & Javanica \\
Leptospira borgpetersenii & Tarassovi & Tarassovi \\
Leptospira interrogans & Canicola & Canicola \\
Leptospira interrogans & Australis & Australis \\
Leptospira interrogans & Autumnalis & Autumnalis \\
Leptospira interrogans & Icterohaemorrhagiae & Copenhageni \\
Leptospira interrogans & Icterohaemorrhagiae & Icterohaemorrhagiae \\
Leptospira interrogans & Pomona & Pomona \\
Leptospira interrogans & Hebdomadis & Hebdomadis \\
Leptospira interrogans & Pyrogenes & Pyrogenes \\
Leptospira interrogans & Sejroe & Wolffi \\
Leptospira interrogans & Djasiman & Sentot \\
Leptospira interrogans & Djasiman & Djasiman \\
Leptospira interrogans & Sejroe & Hardjo, Subtype Hardjoprajtino \\
Leptospira interrogans & Australis & Bratislava \\
Leptospira kirschneri & Grippotyphosa & Grippotyphosa \\
Leptospira kirschneri & Cynopteri & Cynopteri \\
Leptospira noguchii & Panama & Panama \\
Leptospira santarosai & Bataviae & Bataviae \\
\hline
\end{tabular}

For sera screening, a 1:100 dilution was used, and the samples were considered reactive when they showed at least $50 \%$ of agglutination on the microscope field. This dilution was used as a cutoff point, as stated by Nardi Júnior et al. (2006) and Arduino et al. (2009). The reactive sera were titrated with increasing dilutions $(1: 200,1: 400$, $1: 800,1: 1600,1: 3200)$. The highest dilution of the antibody titer was considered, showing agglutination in at least $50 \%$ of the field.
For analysis of the vaccine response and passive immunity transfer, descriptive statistics was used. In order to verify the effect of pregnancy type (singleton or multiple), and the lambs' gender (male or female) on the passive transfer of antibodies, the proportion of reactive and non-reactive animals was analyzed by Chi-square test, with $5 \%$ significance. The statistical analysis was performed using the Bioestat 5.0 software (AYRES et al., 2007). 


\section{RESULTS AND DISCUSSION}

No previous antibodies $(\geq 100)$ were detected before vaccination, for any serogroup of the collection used on MAT. After immunization, every adult sheep vaccinated during this study had specific antibodies detected on MAT. The majority of responses was detected 21 days after administration, when all the ewes were considered responsive (Figure 1). Titrations were low, mostly $1 / 100$.

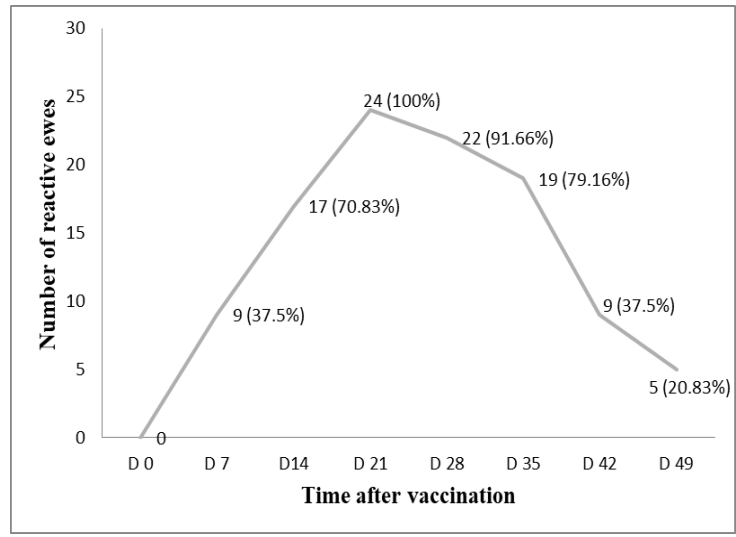

Figure 1. Number of ewes reactive to different serovars on MAT versus time after vaccination for leptospirosis. Uberlândia-MG, 2017.

Four ewes (16.66\%) showed agglutinins for the Canicola serovar. In three ewes, the response for this serovar was observed 21 days after vaccination, and just one ewe had antibodies detected in day 7 after vaccination. Arduino et al. (2009), when searching for antibodies after vaccination for leptospirosis in bovine immunized with a commercial polyvalent vaccine, have not found a significant induction of the humoral immune response for the Canicola serovar.

Five ewes $(20.83 \%)$ in this study had higher titles of antibodies for the Bataviae serovar that occurred 21 days after vaccination. Only one ewe $(4.16 \%)$ was reactive to Grippotyphosa, developing response seven days after vaccination. Castro et al. (2011) found similar results, when evaluating the kinetics of humoral response in young dogs vaccinated for leptospirosis. They did not detect the production of agglutinins for the Grippotyphosa serovar. Their hypothesis is that this serovar is not a good immunogen. Langoni et al. (2002), while studying the dynamics of antibodies production after vaccination in dogs, also observed that the immune response for this serovar did not have good results.

For the Icterohaemorrhagiae serovar, just one ewe $(4.16 \%)$ produced antibodies. The response happened seven days after vaccination and was maintained for 14 days, when antibodies for this serovar could not be detected anymore. According to Tabata et al. (2002), the Icterohaemorrhagiae strain used in the commercial bacterins has low immunogenic capacity.
Eight ewes $(33.33 \%)$ had detectable antibodies titers for the Tarassovi serovar 21 days after vaccination, while for the Pomona serovar, the antibody production occurred in seven ewes (29.15\%), 28 days after vaccination. Studies carried out by Nardi Júnior et al. (2006) in buffalos, and Arduino et al. (2004) in cattle found agglutinins titers for the Pomona serovar starting in day 15 after vaccination.

There was antibody production for the Pyrogenes serovar in three ewes $(12.5 \%)$ in this study. Two of them showed agglutinins titers seven days after vaccination, while one started the production 28 days after.

In this study, $12(50 \%)$ ewes showed detectable antibodies titers for the Hardjo serovar on MAT. Six of them were reactive seven days after immunization. The others showed agglutinin production seven days after receiving the shots. Herrmann et al. (2011) analyzed the antibody production after vaccination in sheep immunized with a monovalent Hardjoprajitno serovar, Norma strain vaccine, and detected antibodies titers on MAT after 30 days of vaccination. Moreira (2009) observed a response to Hardjo serovar in sheep vaccinated with a commercial bacterin only 60 days after the first vaccination.

The titration of vaccinated sheep on this study showed that Hardjo had the best antibody response among the serovars presented in the vaccine. Moreira (2009), who had studied the antiLeptospira agglutinin production in sheep, had 
Evaluation of response...

better titers to the Hardjo serovar with a commercial polyvalent vaccine containing the Bratislava, Icterohaemorrhagiae, Hardjo, Grippotyphosa and Wolffi serovars.

According to Herrmann et al. (2004), the Hardjo serovar is the most reported serovar in reproductive disorders in all continents. Gerritsen et al. (1994) and Vallée et al. (2017) stated that sheep are maintenance hosts for this serovar, and they can eliminate bacteria through urine for long periods.

In this study, an increase of antibody production for the Wolffi serovar was seen around 28 days after vaccination, in three $(12.5 \%)$ of the studied ewes. Moreira (2009), reported that $80 \%$ of the sheep in his research were reactive to the Wolffi serovar, in day 60 after vaccination. Arduino et al. (2004) found antibody production for this serovar in day 15 after vaccination in cattle.

The titers detected for this serovar in the ewes of this study were considered low, under 1:200. Moreira (2009) and Herrmann et al. (2011) found similar titer values in sheep on MAT. These results were expected, since vaccine titers are usually lower than titers induced by natural infection (HERRMANN et al., 2011).

Twenty-four ewes $(100 \%)$ showed antibody production for serovars that were not compounds of the vaccine. The agglutinin production for Leptospira serovariants, such as Andamana, Autumnalis, Djasiman, Hebdomadis and Patoc was observed.

In conformity with Faine et al. (1999), there is no cross-reaction between serogroups, so vaccines may contain endemic serogroups for each region. However, bacteria from the same serogroups possibly share antigens, so cross-reaction between these serovars might occur (TABATA et al., 2002).

In day 21 after vaccination, all ewes showed detectable antibody titers for the Patoc serovar. Titrations were all 1:100, except for five sheep which titration for this serovar was 1:200 on $28^{\text {th }}$ day post immunization. The ewes were reactive for this serovar for a longer period compared to the other serovars tested in this study. This serovar belongs to the species Leptospira biflexa, characterized as a free-living microorganism for being saprophytic. As stated by Moraes et al. (2010), this serovar can be related to cross-reactivity with other pathogenic serovars, or can indicate premature serologic reaction, which makes it an important diagnostic tool.

No previous antibodies $(\geq 100)$ were detected before vaccination, for any serovar of the collection used on MAT. However, on the posterior
CUCCATO, L. P.et al.

sampling, four ewes (16.66\%) had antibodies for the Andamana serovar, three (12.5\%) for the Autmnalis serovar, and six (25\%) for Djasiman and Hebdomadis. These serovars were not constituents of the bacterin chosen for this study, and besides that, they belong to different serogroups. A probable explanation for this fact would be a natural exposure and infection by those agents.

One animal was reactive to eight of the ten serovars present in the vaccine. None of the animals produced agglutinins against all serovars that constitute the vaccine used in this study.

The humoral immune response caused by the administration of the vaccine was heterogeneous, because it did not induce equal antibody production in all ewes. Yet, it had a shortterm response, since 49 days after vaccination, antibodies for the vaccine serovars were not detected anymore. Herrmann et al. (2011) also observed a short-term duration of post-vaccine agglutinins in sheep that were vaccinated with a single shot of a monovalent Hardjo serovar vaccine.

According to Siddique and Shah (1990), commercial polyvalent vaccines do not induce similar serologic responses to all Leptospira serovars. That's probably because there's a difference in the final antigen concentration, or because of a possible suppression of the antigenic response among the vaccine's serovars.

Tizard (2014) stated that the response induction of a vaccine is not absolute and is never equal for every animal in the population. Genetic and environmental factors can affect the vaccine response. Moreover, whenever there is immune suppression by parasitism, malnutrition, stress or serious illness, failure of the vaccine response can be observed.

Nardi Júnior et al. (2003) emphasized that the duration and magnitude of the antibody titers can be related to the production method of the commercial vaccines used in Brazil, which employ completely inactivated bacterial cultures (bacterins). For Siddique and Shah (1990), Leptospira is an antigen that induces a low response for a short period.

The 24 ewes of this experiment gave birth to 32 lambs, 16 of each gender; of which, 16 were born to singleton-bearing ewes, and 16 were born to multiple-bearing ewes. Twenty-one (65.62\%) lambs were reactive on MAT for the blood sampling performed 24-48 hours after birth. Seven (21.87\%) lambs were reactive on MAT 10 days after birth. On the third blood collection, only one lamb was reactive on MAT (Figure 2). 

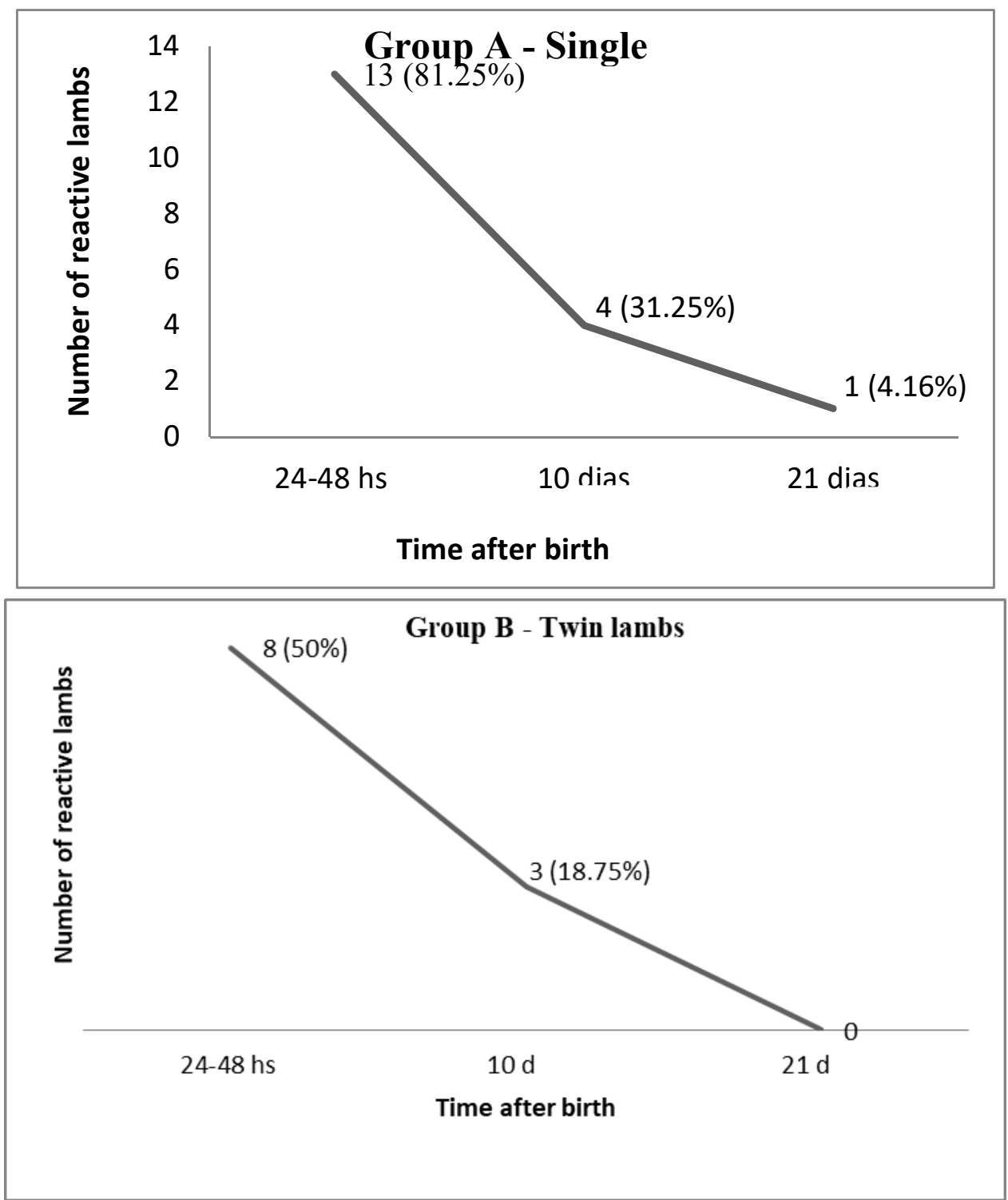

Figure 2. Number of lambs in group A (single gestation) and group B (multiple gestation) reactive on the Microscopic Agglutination Test (MAT), for different serovars related to time after birth. UberlândiaMG, 2017.

The number of reactive lambs on MAT decreased gradually after birth on both groups, A and B. According to Tizard (2014), until approximately 24 hours after birth, the colostrum proteins do not go through proteolytic degradation in the digestive tract and can be fully absorbed by the offspring. At this point, it is possible to verify immunoglobulin levels similar to the ones in adult animals. After the absorption is ceased, the levels of maternal antibodies start to decrease as they get distributed and catalyzed.

The biological half-life of immunoglobulins varies from 7 to 18 days in sheep (DOMINGUEZ et al., 2001), which is similar to the period of time observed in this study.

Significant statistical difference $(\mathrm{p}$ value $=0.0627$ ) was not seen between single lambs and twins that received immunoglobulins by passive transfer in the first collection, performed 24 hours after birth.

In the collections performed at 10 and 21 days after birth, significant statistical difference (Pvalue 10 days $=0.6689 ; \mathrm{P}$-value 21 days $=0.3096$ ) was not seen. Thus, the passive immunity transfer through colostrum did not differ between groups A (singletons) and B (twins), in any of the analyzed periods. Alves et al. (2015) analyzed the colostrum composition and the passive immunity transfer in lambs, and verified that the number of fetuses did not affect the IgG's concentration in the colostrum during gestation.

When comparing passive immunity transfer between lambs per gender, no significant statistical difference was seen between male and female lambs 
(p-value $=0.2642)$. Turquino et al. (2011) also did not find any differences in IgG's concentrations between genders.

Eleven lambs (34.37\%) did not show antibodies on MAT, even though it was expected to observe antibodies acquired through colostrum in all lambs. Four of these animals probably did not receive antibodies from their mothers because they showed clinical signs of mastitis. Santos et al. (2013) stated that the invasion of the mammary gland by microorganisms during peripartum decreases the synthesis and secretory activity by the epithelial cells during colostrogenesis. This way, mastitis might have contributed for failure in the immunity transfer in those animals.
Although mastitis can affect the passive immunity transfer, this is not the only possible cause, according to Santos et al. (2013). Other factors such as failure in colostrum production and failure in immunoglobulin absorption may influence the passive immunity transfer (TIZARD, 2014).

Most of lambs had a 1:100 titer reaction to the same serovar detected on their dams (Table 3). The twin lambs presented reactivity to the same serovars on MAT, except for the twins of ewe 13, which reacted differently for the Canicola and Tarassovi serovars. Eleven lambs, three of them being twins, showed reaction on MAT for the serovars present in the vaccine. However, these serovars did not correspond to the same serovars to which the mothers were reactive.

Table 3. Correspondence between seroconversion in ewes and transfer of colostrum antibodies to the newborn lambs. Uberlândia, MG-2017.

\begin{tabular}{|c|c|c|c|}
\hline Ewe & SEROVARS & Lambs & SEROVARS \\
\hline 1 & Pat & 1 & NEGATIVE \\
\hline 2 & Can, Har, Pom, Tar, Wol, Heb, Pat & 2 & Can, Har, Pom \\
\hline 3 & And, Pat & 3 & ${ }^{*}$ Can, *Har, Pat, *Pom, *Pyr,*Tar \\
\hline 4 & Har, Pom, Pyr, Tar, Heb, Pat & 4 & *Can, Har,* Ict, Pat, Pom, Pyr, Tar, *Wol \\
\hline 5 & Pat & 5 & *Har, Pat, *Pom, *Pyr, *Tar \\
\hline 6 & Bat, Can, Har, Aut, Dja, Pat & 6.I; 6.II & NEGATIVE \\
\hline 7 & Pat & 7 & ${ }^{*}$ Can, *Dja, ${ }^{*} H a r, *$ Ict, Pat, ${ }^{*}$ Pom, ${ }^{*}$ Wol \\
\hline 8 & Bat, Can, Gri, Har, Ict, Pom, Pyr, Tar, Aut, Dja, Pat & 8 & Can, Dja, Har, Ict, Pat, Pom, Pyr, Tar, *Wol \\
\hline 9 & Har, Pom, Pyr, Tar, Dja, Pat & 9 & Dja, Har, *Ict, Pat, Pom, Pyr, Tar \\
\hline 10 & Can, Har, Heb, Pom, Tar, Wol, Pat & 10 & Can, Har, Heb, ${ }^{*}$ Ict, Pat, Pom \\
\hline 11 & Pat & 11.I; 11.II & *Dja, ${ }^{*}$ Har,Pat, ${ }^{*}$ Pom, ${ }^{*}$ Pyr, ${ }^{*}$ Tar, ${ }^{*}$ Wol \\
\hline 12 & Har, Tar, Bat, Dja, Pat & 12.I; 12.II & NEGATIVE \\
\hline \multirow[t]{2}{*}{13} & Tar, Pat & 13.I; & *Can, *Har, Pat \\
\hline & & 13;II & *Har, Tar, Pat \\
\hline 14 & Pat & 14 & Pat \\
\hline 15 & Pat & 15.I; 15.II & *Har, Pat \\
\hline 16 & Har, Heb, Pat & 16 & Har, Heb, Pat \\
\hline 17 & Har, Pat, And & 17.I; 17.II & NEGATIVE \\
\hline 18 & Pat & 18 & *Har \\
\hline 19 & Har, Pom, Wol, And, Bat, Dja, Heb, Pat & 19.I; 19.II & Har \\
\hline 20 & And, Pat & 20 & Pat \\
\hline 21 & Pat & 21 & NEGATIVE \\
\hline 22 & Pat & 22 & Pat \\
\hline 23 & Har, Pat & 23 & NEGATIVE \\
\hline 24 & Har, Pom, Wol, Aut, Bat, Dja, Heb, Pat, & 24.I; 24.II & NEGATIVE \\
\hline
\end{tabular}

And: Andamana; Aut: Autumnalis; Bat: Bataviae; Can: Canicola; Dja: Djasiman; Gri: Grippotuphosa; Har: Hardjo; Heb: Hebdomadis; Ict: Icterohaemorrhagiae, Pat: Patoc; Pom: Pomona; Pyr: Pyrogenes; Tar: Tarassovi; Wol: Wolffi.

* Serovars that did not match with the serovars to which ewes were reactive.

The hypothesis is that the prozone effect had occurred on MAT for the ewes, since the lambs were reactive to the vaccine's serovars. This effect happens when there are high concentrations of serum antibodies, which inhibit agglutination (TIZARD, 2014).

The immunoglobulin $\mathrm{G}(\mathrm{IgG})$ is prevalent in domestic animals colostrum, and represents the immunological experience of the mothers during their lives, which is the whole history of exposure to antigens and B cells response (TIZARD, 2014). The property on where this research was conducted had a vaccination protocol for leptospirosis for every six months, so all ewes had been exposed to the vaccine's antigens in previous immunizations.

Vaccination for leptospirosis is an efficient measure for prevention and control of the disease, especially when used properly and frequently. The 
Evaluation of response...

immunization of pregnant ewes with anti-Leptospira bacterins is safe, and protects both ewes and lambs after birth.

\section{CONCLUSIONS}

The vaccine induced humoral immune response for Leptospira's serovars in pregnant ewes. The antibodies levels were not very persistent and were represented by low titers. The majority of sheep seroconversion occurred 21 days after
CUCCATO, L. P.et al.

vaccination, and the Hardjo serovar, from all the serovars contained in the vaccine, had the biggest response in number of ewes.

This study demonstrated that there was an anti-Leptospira antibody transfer via colostrum to newborn lambs. Also, a greater number of lambs reactive on MAT right after birth was detected. The type of gestation (singleton or multiple) and the lambs' gender did not influence the passive immunity transfer between ewes and lambs in this research.

RESUMO: A leptospirose é uma doença frequentemente subestimada em rebanhos ovinos e leva a grandes prejuízos à ovinocultura. $\mathrm{O}$ objetivo deste estudo foi avaliar a resposta imune humoral em ovelhas gestantes, após imunização com uma vacina polivalente comercial contra leptospirose, bem como verificar a transmissão dos anticorpos adquiridos às crias, pelo colostro. Para isto, 24 ovelhas gestantes foram vacinadas. Amostras de sangue foram coletadas pré-imunização, bem como 7, 14, 21, 28, 35, 42 e 49 dias após. Para avaliar a transferência passiva de anticorpos, os 32 cordeiros que nasceram dessas ovelhas foram amostrados nas primeiras 48 horas após o nascimento, bem como com 10 e 21 dias de vida. Os cordeiros foram divididos em dois grupos: partos simples (Grupo $\mathrm{A} ; \mathrm{n}=16$ ) e partos gemelares (Grupo $\mathrm{B}, \mathrm{n}=16$ ). O soro sanguíneo foi submetido à prova de Soroaglutinação Microscópica (MAT), na qual 21 sorovares de Leptospira foram testados. $\mathrm{O}$ número de ovelhas reativas à MAT aumentou gradualmente até os 21 dias após imunização, com posterior decréscimo. De todos os sorovares presentes na vacina, a maior parte dos animais soroconverteu para o sorovar Hardjoprajtino, do sorogrupo Serjoe. Anticorpos anti-Leptospira passaram pelo colostro e puderam ser detectados no soro dos cordeiros entre 24 e 48 horas após o nascimento. Foi observado que $65,5 \%$ (21 de 32) cordeiros foram reativos. Em coletas subsequentes, realizadas 10 e 21 dias após o nascimento, houve um decréscimo no número de animais reativos à MAT. Não houve diferença significativa na transferência de anticorpos entre cordeiros de partos simples e gemelares.

PALAVRAS-CHAVE: Imunização. Leptospirose. Ovinos.

\section{REFERENCES}

ADLER, B. Leptospira and Leptospirosis: Current Topics in Microbiology and Immunology. Melboure, Australia: Springer, 2015. 293 p.

ALVES, A. C.; ALVES, N. G.; ASCARI, I. J.; JUNQUEIRA, F. B.; COUTINHO, A. S.; LIMA, R. R.; PÉREZ, R. O.; DE PAULA, S. O.; FURUSHO-GARCIA, I. F.; ABREU, L. R. Colostrum composition of Santa Inês sheep and passive transfer of immunity to lambs. Journal of Dairy Science, Champaing, IL, v. 98, n. 6, p. 3706-3716, 2015. Disponível em: https://doi.org/10.3168/jds.2014-7992

ARDUINO, G. G. C.; GIRIO, R. J. S.; FREIRE, M. M.; MARCHIORI FILHO, M. Anticorpos contra Leptospira spp. em bovinos leiteiros vacinados com bacterina polivalente comercial: perfil sorológico frente a dois esquemas de vacinação. Ciência Rural, Santa Maria, RS, v. 34, n. 3, p.865-871, 2004. Disponível em: http://dx.doi.org/10.1590/S0103-84782004000300032

ARDUINO, G. G. C.; GIRIO, R. J. S.; MAGAJEVSKI, F. S.; PEREIRA, G. T. 2009. Títulos de anticorpos aglutinantes induzidos por vacinas comerciais contra leptospirose bovina. Pesquisa Veterinária Brasileira, Seropédica, RJ, v. 7, n. 29, p.575-582. Disponível em: http://dx.doi.org/10.1590/S0100-736X2009000700013

AYRES, M.; AYRES JÚNIOR, M.; AYRES, D. L.; SANTOS., A. S. DOS. BioEstat 5.0: aplicações estatísticas nas áreas das ciências biológicas e médicas. Belém: MCT; IDSM; CNPq., 2007. 364 p. 
BRASIL. Ministério da Saúde. Fundação Nacional da Saúde. Centro Nacional de Epidemiologia. Manual de Leptospirose. 2a . ed., Brasília: Fundação Nacional de Saúde, 98 p. 1995.

CASTRO, J. R.; SOUZA, M. A.; SALABERRY, S. R. S.; GUIMARÃES, E. C.; RIBEIRO, A. M. C. L. Cinética da resposta imune humoral de cães jovens imunizados contra Leptospira interrogans. Pesquisa Veterinária Brasileira, Seropédica, RJ, v. 31, n. 11, p. 1000-1005, 2011. Disponível em: http://dx.doi.org/10.1590/S0100-736X2011001100011

CICERONI, L.; LOMABRDO, D.; PINTO, A.; CIARROCCHI, S.; SIMEONI, J. Prevalence of Antibodies to Leptospira Serovars in Sheep and Goats in Alto Adige-South Tyrol. Journal of Veterinary Medicine Series B, [S. L.] v. 47, n. 3, p.217-223. 2000. Disponível em: https://doi.org/10.1046/j.1439-0450.2000.00333.x

DOMINGUEZ, E.; PEREZ, M.D.; PUYIL, P.; SANCHEZ, L.; CALVO, M. Specific immunoglobulins in serum of newborn lambs fed with a single dose of colostrum containing anti-peroxidase IgG. Research In Veterinary Science, [S.L.], v. 70, n. 3, p.275-279, 2001. Disponível em: https://doi.org/10.1053/rvsc.2001.0474

ELLIS, W.A. Leptospirosis as a cause of reproductive failure. Veterinary Clinics of North America: Food Animal Practice, [S. L.] v. 10, n. 3, p. 463-478, 1994. Disponível em: https://doi.org/10.1016/S07490720(15)30532-6

FAINE, S.; ADLER, B.; BOLIN, C.; PEROLAT, P. Leptospira and leptospirosis. 2 ed. Mellbourne: MediSci, 1999.

GERRITSEN, M. J.; KOOPMANS M.J.; PETERSE, D.; OLYHOEK, T. Sheep as maintenance host for Leptospira interrogans serovar Hardjo subtype Hardjobovis. American Journal of Veterinary Research, [S. L.], v. 55, p.1232-1237, 1994. Disponível em: https://www.ncbi.nlm.nih.gov/pubmed/7802389

HERNÁNDEZ-CASTELLANO, L.; MORALES-DELANUEZ, A.; SANCHES-MACIAS, D.; MORENOINDIAS, I.; TORRES, A.; CAPOTE, J.; ARGUELLO, A.; CASTRO, N. The effect of colostrum source (goat vs. sheep) and timing of the first colostrum feeding ( $2 \mathrm{~h}$ vs. $14 \mathrm{~h}$ after birth) on body weight and immune status of artificially reared newborn lambs. Journal of Dairy Science, Champaing, IL, v. 98, n. 1, p.204-210, 2015. Disponível em: https://doi.org/10.3168/jds.2014-8350

HERRMANN, G. P.; LAGE. A. P.; MOREIRA, E. C.; HADDAD, J. P. A.; RESENDE, J. R.; RODRIGUES, R. O.; LEITE, R. C. Soroprevalência de aglutininas anti-Leptospira spp. em ovinos nas mesorregiões sudeste e sudoeste do estado do Rio Grande do Sul, Brasil. Ciência Rural, Santa Maria, v.34, p.443-448, 2004. Disponível em: http://dx.doi.org/10.1590/S0103-84782004000200017

HERRMANN, G.P., RODRIGUES, R.O., VIDAL, C.E.S., MACHADO, G., MOREIRA, E.C.; LEITE, R.C. Curva de anticorpos pós-vacinais em ovinos imunizados com uma ou duas doses de bacterina oleosa antileptospirose, produzida com a sorovariedade Hardjo, tipo Hardjoprajitno, estirpe Norma, isolada no Brasil. Pesquisa Veterinária Brasileira, Seropédica, RJ, v. 31, n. 8, p.683-689, 2011. Disponível em: http://dx.doi.org/10.1590/S0100-736X2011000800009

HIGINO, S.S. DOS S.; AZEVEDO, S.S. DE. Leptospirose em pequenos ruminantes: situação epidemiológica atual no Brasil. Arquivos Instituto Biológico, São Paulo, SP, v. 81, n. 1, p.86-94, 2014. Disponível em: http://dx.doi.org/10.1590/S1808-16572014000100017

INSTITUTO BRASILEIRO DE GEOGRAFIA E ESTATÍSTICA. Infográficos: Dados Gerais do município, 2014. Disponível em: < www.cidades.ibge.gov.br/painel/painel.php?codmun=317020 >, Acesso em 05/01/2017. 
LANGONI, H.; PIMENTEL, V. L.; SILVA, A. V.; LUCHEIS, S.B.; DENARDI, M. B. Avaliação da dinâmica de anticorpos pós-vacinais contra Leptospira spp. em cães vacinados, pela prova de SAM. Ars Veterinária, Jaboticabal,SP, v. 18, p.54-61. 2002.

LILENBAUM, W.; VARGES, R.; RISTOW, P.; CORTEZ, A.; SOUZA, S. O.; RICHTZENHAIN, L. Z.; VASCONCELLOS, S. A. Identification of Leptospira spp. carriers among seroreactive goats and sheep by Polymerase Chain Reaction. Research in Veterinary Science, [S. L.], v. 87, n. 1, p.16-19, 2009. Disponível em: https://doi.org/10.1016/j.rvsc.2008.12.014

MARTINS, G.; PENNA, B.; HAMOND, C.; LEITE, R. C. K.; SILVA, A.; FERREIRA, A.; BRANDÃO, F.; OLIVEIRA, F.; LILENBAUM, W. Leptospirosis as the most frequent infectious disease impairing productivity in small ruminants in Rio de Janeiro, Brazil. Tropical Animal Health and Production, [S. L.], v. 44, n. 4, p.773-777, 2011. Disponível em: https://doi.org/10.1007/s11250-011-9964-4

MORAES, C. C. G. DE; KURODA, R. B. DOS S.; PINHO, A. P. V. B.; YWASAKI, F.; MENESES, A. M. C.; MARTINS, A. V.; AMARAL JÚNIOR, J. M. DO; DIAS, H. L. T.; VASCONCELOS, S. A. Pesquisa de anticorpos para sorovares de Leptospira interrogans patogênicas em equídeos criados na ilha de Algodoal, Estado do Pará. Revista de Ciências Agrárias, Belém, PA, v. 53, n. 2, p.188-194, 2010. Disponível em: https://doi.org/10.4322/rca.2011.027

MOREIRA, E. C. Avaliação de Métodos para erradicação de leptospiroses em bovinos leiteiros. 1994. 94 f. Tese (Doutorado) - Programa de Pós-Graduação em Medicina Veterinária, Escola de Veterinária da Universidade Federal de Minas Gerais, Belo Horizonte, MG.

MOREIRA, R. Q. Prevalência de anticorpos anti-Neospora-caninum, anti-Toxoplasma gondii e antiLeptospira spp. e resposta vacinal contra Leptospira spp. em rebanho ovino no município de Uberlândia, MG. 2009. 61 f. Dissertação (Mestrado) - Programa de Pós-Graduação em Medicina Veterinária, Universidade Federal de Uberlândia, Uberlândia, MG. Disponível em: https://repositorio.ufu.br/handle/123456789/12962

NARDI JÚNIOR, G.; GENOVEZ, M. E.; RIBEIRO, M. G.; JORGE, A. M.; CASTRO, V.; CARREIRA, R. C. Níveis de aglutininas anti-leptospira no soro de búfalas (Bubalus bubalis) vacinadas com dois tipos de vacinas comerciais anti-leptospirose: resultados parciais. Arquivos Instituto Biológico, São Paulo, v. 70, n. 3, p.1-4; 2003.

NARDI JÚNIOR, G.; RIBEIRO, M. G.; VASCONCELLOS, S. A.; MEGID, J.; JORGE, A. M.; GERONUTTI, L.; MORAIS, Z. M. Perfil de aglutininas anti-Leptospira em bezerras búfalas vacinadas com bacterina pentavalente comercial contra leptospirose. Arquivo Brasileiro Medicina Veterinária e Zootecnia, Belo Horizonte, MG, v. 58, n. 3, p. 299-304, 2006. Disponível em: http://dx.doi.org/10.1590/S010209352006000300002

PUCHE, R.; FERRÉS, I.; CARABALLO, L.; RANGEL, Y.; PICARDEAU, M.; TAKIFF, H.; IRAOLA, G. Leptospira venezuelensis sp. nov., a new member of the intermediate group isolated from rodents, cattle and humans. International Journal of Systematic and Evolutionary Microbiology, [S. L.] v. 68, n. 2, p.513-517, 2018. Disponível em: https://doi.org/10.1099/ijsem.0.002528

SANTOS, G. G. F.; DESCHK, M.; SILVA, A. K. G.; PÓLO, T. S.; MARINHO, M.; PEIRÓ, J. R.; MENDES, L. C. N.; FEITOSA, F. L. F. Proteinograma sérico de bezerros recém-nascidos alimentados com colostro de vacas com mastite. Brazilian Journal of Veterinary Research and Animal Science, São Paulo, v. 50, n. 3 , p.188-197, 2013. Disponível em: http://dx.doi.org/10.1590/1808-1657000022015

SIDDIQUE, I. H.; SHAH, S. M. Evaluation of polyvalent leptospiral vaccine in hamsters. Indian Veterinary Journal., Madras, v. 67, p. 1006-1010, 1990. 
SILVA, A. S. DA; SOUZA, C. F.; BALDISSERA, M. D.; VON LAER, A. E.; LOVATO, L. T.; SARTURI, J. A.; HERRMANN, G. P.; MOURA, A. B. DE; FAVARETTO, J. A.; FRIAS-DE-DIEGO, A.; MACHADO, G. Relation of reproductive disturbance in sheep and Leptospira interrogans serovar Icterohaemorrhagiae infection: Impacts on cellular oxidation status. Microbial Pathogenesis, [S.L.], v. 130, p.65-70, maio 2019. Disponível em: https://doi.org/10.1016/j.micpath.2019.02.029

TABATA, R.; SCANAVANI, NETO H.; ZUANAZE, M. A. F.; OLIVEIRA, E. M. D.; DIAS, R. A.; MORAIS, Z. M.; ITO, F. H.; VASCONCELLOS, S. A. Cross neutralizing antibodies in hamsters vaccinated with leptospiral bacterins produced with three serovars of serogroup Serjoe. Brazilian Journal Microbiological, São Paulo, SP, v. 33, p. 265-268, 2002. Disponível em: http://dx.doi.org/10.1590/S1517-83822002000300016

TIZARD, I. R. Imunologia Veterinária. 9 ed. São Paulo: Elsevier, 2014. 551 p.

TURQUINO, C. F., FLAIBAN, K. K. M. C., LISBÔA, J. A. N. Transferência de imunidade passiva em cordeiros de corte manejados extensivamente em clima tropical. Pesquisa Veterinária Brasileira, Seropédica, RJ, v. 31, n. 3, p.199-205, 2011. Disponível em: http://dx.doi.org/10.1590/S0100-736X2011000300003

VALLÉE, E.; RIDLER, A. L.; HEUER, C.; COLLINS-EMERSON, J. M.; BENCHOP, J.; WILSON, P. R. Effectiveness of a commercial leptospiral vaccine on urinary shedding in naturally exposed sheep in New Zealand. Vaccine, Guildford, v.35, n.9, p. 132-1368, mar., 2017. Disponível em:

http://dx.doi.org/10.1016/j.vaccine.2016.04.037 